\title{
The Impact Of Performance-Based CEO And CFO Compensation On Internal Control Quality
}

\author{
Kevin Kobelsky, Ph.D., University of Michigan-Dearborn, USA \\ Jee-Hae Lim, Ph.D., University of Waterloo, Canada \\ Ranjini Jha, Ph.D., University of Waterloo, Canada
}

\begin{abstract}
We examine the effects of compensation on the quality of internal control and provide the first evidence relating the time horizon of ex ante performance-based compensation incentives and internal control quality over financial reporting in the SOX 404 era. Specifically, we find that for CEOs and CFOs, the sensitivity of the option portfolio to stock price changes and the proportion of compensation received from long-term incentive plans are related to the propensity to report internal control weaknesses during the period 2004-2006. These effects are negative for long-term incentives but positive or insignificant for short-term incentives for both CEOs and CFOs, who have the primary responsibility for the financial reporting process. Compensation sensitivity is also more strongly related to more severe company-level than account-specific control weaknesses. This company-level weakness relation is stronger for the CFO, who has the primary responsibility for the processes generating financial information and for the financial reporting by the firm. Our findings indicate that SOX disclosures harness the power of compensation schemes to improve internal control quality.
\end{abstract}

Keywords: CEO \& CFO Compensation; Internal Control Quality; Financial Reporting; Sarbanes-Oxley (SOX)

\section{INTRODUCTION}

hile performance-based executive compensation has become one of the primary tools for aligning owner and managerial interests (Jensen and Murphy, 1990), a significant body of research has found that managerial incentives from compensation are positively associated with subsequent manipulation of earnings for chief executive officers (CEOs) (Bergstresser and Philippon, 2006; Burns and Kedia, 2006; Cheng and Warfield, 2005; Cohen et al., 2008; Cornett et al., 2008) and chief financial officers (CFOs) (Feng et al., 2011; Jiang et al., 2010). The incentive to manipulate earnings arises from the limited downside risk associated with detection of the manipulation, creating convexity in CEO and CFO wealth relative to compensation scheme sensitivity (Burns and Kedia, 2006). In response to several high-profile accounting scandals, the SarbanesOxley Act (SOX hereafter) was enacted to reduce the ability of managers to manipulate financial reporting.

Notwithstanding the effect of performance-based incentives on earnings manipulation, research has not yet explored the impact of these incentives on the level of internal control implemented by management in the SOX era. If an impact does exist, it may be moderated by the time horizon of the incentives (Burns and Kedia, 2006) or the severity of weaknesses reported (Doyle et al., 2007b). CEOs and CFOs are of particular interest because they are specifically identified by SOX and may respond differently to performance-based incentives (Jiang et al., 2010). This gives rise to three central questions. Does performance-based compensation scheme sensitivity enhance or diminish internal control quality? Does the impact of sensitivity vary between short- and long-term time horizon incentives, or with the severity of the weaknesses reported i.e., company-level or account-specific weakness? Finally, is this relation different between CEOs and CFOs because of their different roles? 
In this paper, we consider two opposing forces describing the effect of compensation sensitivity on internal control over financial reporting in the SOX Section 404 era. 1. Higher-sensitivity compensation schemes increase the incentive to manipulate earnings in order to benefit in the short-term from higher stock prices; this reduces managers' incentives to maintain effective systems of internal control (a positive relation between compensation sensitivity and the likelihood of reporting any material weaknesses in internal control (hereafter, ICW). 2. Highersensitivity compensation schemes increase the incentive to minimize occurrences of ICW to avoid their disclosure and the related reduction in executive wealth (a negative relation). Potential wealth effects include personal fines and criminal penalties, ${ }^{1}$ declines in stock price (and compensation based on it) (Zhang, 2007), bonus clawbacks (Carter et al., 2009; Hoitash et al., 2012), and dismissal or related labor market penalties for senior executives (Collins et al., 2009; Li et al., 2010).

Given that, we hypothesize that the net effect of these two forces is to better align the interests of managers and shareholders with respect to enhancing internal control, implying a negative association between compensation sensitivity and the reporting of ICW. We expect the effect of incentives to vary with their time horizon, so that longterm incentives reduce the likelihood of reporting control weaknesses, and short-term incentives have no net effect. Long-term incentives to be received in the future have a lower present value than an equal amount of short-term incentives due to uncertainty related to their realization and the time value of money. This effect is expected to be more salient for company-level control weaknesses because of the critical roles that 'tone at the top' plays in such weaknesses, in contrast to account-specific weaknesses, which are more likely to arise from functionally specific, localized transaction processes.

We investigate these relations using a sample of 302 firms (267 for CFOs) that disclose ICWs from 2004 through 2006 relative to a control sample of 3,352 firms (2,918 for CFOs) that do not make any such disclosure. ${ }^{2}$ Sensitivity is defined as the change in value of total compensation resulting from a one percent change in firm stock price (Burns and Kedia, 2006; Core and Guay, 2002; Feng et al., 2011; Jiang et al., 2010). The components examined include stock options, restricted and unrestricted equity holdings, long term incentive plan payouts, and the sensitivity of salary and bonus incentives to changes in net income. To examine the potential effect of incentive time horizon, we distinguish between vested and unvested options and categorize each type of compensation as short- or long-term.

The results indicate that the level and time horizon of CEO and CFO contingent compensation, in particular long-term incentives including unvested options and long-term incentive plan payouts, significantly reduce the likelihood of a firm reporting one or more ICWs. Unrestricted equity holdings, which were classified as having a short-term time horizon compensation, were also found to be negatively related to ICWs, but only for CFOs. Our findings contribute to the literature by providing the first evidence concerning how SOX enhances earnings quality, beyond imposition of fines and imprisonment: it harnesses the power of long-term compensation to enhance internal control over financial reporting.

The disaggregation of ICWs by severity level confirms that compensation sensitivity is more strongly negatively related to company-level weaknesses than account-specific weaknesses, particularly for CFOs. Optionbased sensitivity driven by unvested options is predictive of company-level but not account-specific weaknesses for both CEOs and CFOs. CFO compensation sensitivity arising from restricted and unrestricted equity holdings and long term incentive plan payments are also significant. This finding contributes to research indicating that the two types of weaknesses are associated with different causal variables in the SOX 404 era (Doyle et al., 2007a).

\footnotetext{
${ }^{1}$ Section 304 requires that CEOs and CFOs reimburse bonuses and/or incentives/equity-based compensation received and any profit realized from the sales of securities of the issuer in the 12 months following an accounting restatement. Section 906 further specifies fines of up to $\$ 5$ million and/or 20 years of incarceration for CEOs and CFOs who certify a control report they know to be inaccurate.

${ }^{2}$ Section 404 became effective for fiscal years ending after November 15, 2004 for the largest firms (accelerated filers). Accelerated foreign private issuers (foreign firms not having a majority of their shares held and assets located in the US) have been required to comply with these requirements for fiscal years after July 15, 2007. Non- accelerated filers (public float less than $\$ 75$ million) are required to provide a management report on internal control for fiscal years ending on or after December 15 , 2007, and an auditor's attestation on internal control for fiscal years ending on or after June 15, 2010. Section 302 preceded Section 404 and applies to all SEC registrants effective August 29, 2002.
}

$914 \quad$ Copyright by author(s) $\underline{\text { Creative Commons License CC-BY }}$

2013 The Clute Institute 
Overall, the findings suggest that firms may enhance internal control by emphasizing long-term contingent compensation for both CEOs and CFOs. CEO and CFO effects are consistent for all forms of compensation except unrestricted equity holdings, which reduce the likelihood of reporting weaknesses for CFOs, but not for CEOs. This negative relation parallels the findings of Jiang et al. (2010) for post-SOX discretionary accruals. This indicates that the incentives of both executives have a role to play in internal control effectiveness, in contrast to the dominance of CEO sensitivity found by Feng et al. (2011). This implication may be of practical interest to regulators, investors, and other financial statement users evaluating the quality of financial reporting at firms with high levels of performance-based compensation. Furthermore, the findings are relevant to board members attempting to address internal control in the design of compensation schemes.

\section{LITERATURE REVIEW AND HYPOTHESES DEVELOPMENT}

Managers contemplating the intentional manipulation of earnings in order to meet performance targets must weigh the incentive to manipulate for achieving the target against the penalty associated with the discovery and disclosure of manipulation (Ashbaugh-Skaife et al., 2007; Sen, 2007). Without mechanisms for discovering, disclosing and penalizing manipulation, earnings are more likely to be over- or under-reported by self-interested managers. Figure 1 depicts extant research investigating the relation between compensation scheme structure (sensitivity) and other firm characteristics, including internal control, manipulation of accounting figures, related penalties and benefits.

\section{Compensation Sensitivity and Earnings Manipulation}

Consistent with popular media reports of several high-profile accounting scandals including Enron, WorldCom and Global Crossing, a significant body of research has found a positive effect of performance-based compensation sensitivity on subsequent earnings manipulation after controlling for other firm characteristics (Figure 1 paths (i) and (ii)). These studies have examined both manipulations that are allowable under generally accepted accounting principles and those that are not; they examine both pre-SOX accrual manipulations and accounting restatements (i.e., prior to August 2002) (Bartov and Mohanram, 2004; Bergstresser and Philippon, 2006; Burns and Kedia, 2006; Cheng and Warfield, 2005; Cornett et al., 2008; Efendi et al., 2007; Erickson et al., 2006; Feng et al., 2011; Goldman and Slezak, 2006; Harris and Bromiley, 2007; Johnson et al., 2009; McVay et al., 2006; O'Connor et al., 2006), and post-SOX accrual manipulations (Cohen et al., 2008; Jiang et al., 2010; Larcker et al., 2007; Veenman et al., 2011). All studies find positive correlations except Jiang et al. (2010), which finds a negative relation between CFO compensation and forward-looking discretionary accruals in the post-SOX era and Erickson et al. (2006) who find no relation in the pre-SOX era. This positive relationship is consistent with findings in the compensation literature that find compensation sensitivity is positively related to risk-taking (e.g., Belkhir and Chazi, 2010).

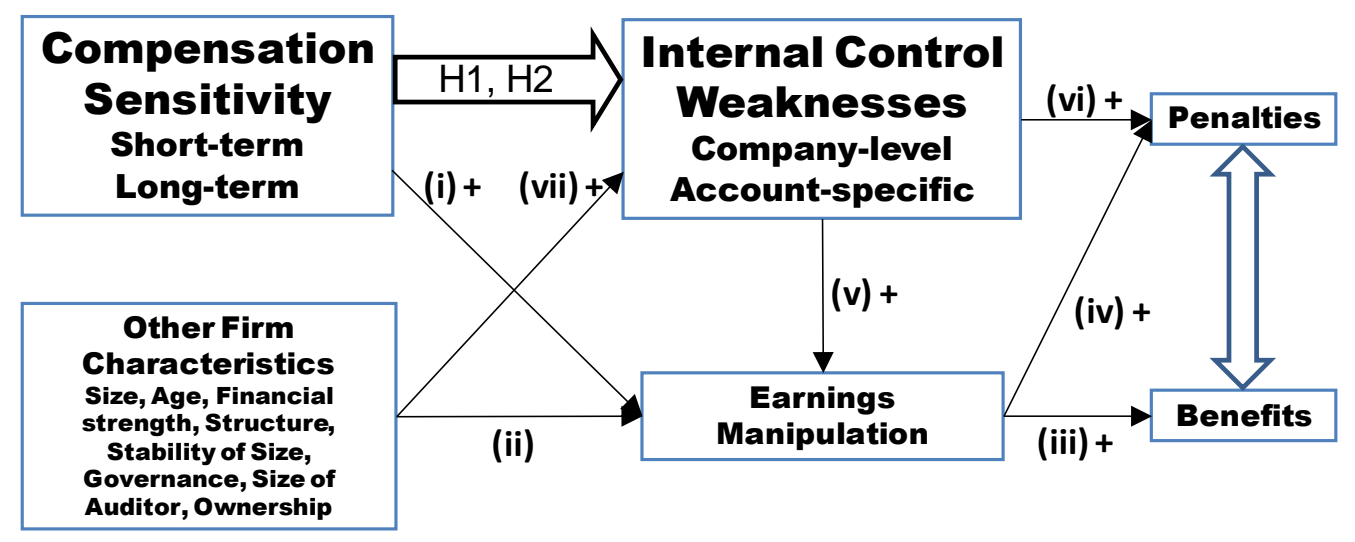

Arrows (i) - (vii) depict prior research streams and relation sign

Figure 1. Research Model in relation to Prior Research Investigating Firm Characteristics, Compensation Sensitivity, Internal Control, Earnings Manipulation and Penalties 


\section{Earnings Manipulation, Benefits and Penalties}

Both the positive and negative outcomes arising from earnings manipulations have been examined in empirical research. To the extent that managers foresee them, these outcomes act as incentives. Burns and Kedia (2008) find strong evidence of significant ex post benefits arising from manipulation (Figure 1 path (iii)): executives at firms engaging in deliberate earnings manipulations exercise $60 \%$ more options than their counterparts at other firms. This occurs despite the significant penalties to executives when manipulation is detected and disclosed (Figure 1 path (iv)). Restatements lead to a significant decrease in share value both pre-SOX (Palmrose et al., 2004) and to a lesser extent, post-SOX (Burks, 2011; Hranaiova and Byers, 2007), directly reducing the value of equitybased incentives. Beyond these immediate effects, executives (Burks, 2010; Cheng and Farber, 2008; Collins et al., 2009; Desai et al., 2006; Hennes et al., 2008; Li et al., 2010) and directors (Srinivasan, 2005) of firms disclosing accounting errors are much more likely to leave the firm. CFOs leaving the firm are subject to stiff labor-market penalties (Collins et al., 2009), while those remaining with the firm are subject to significant reductions in bonus payments (Burks, 2010; Hoitash et al., 2012). The positive relation found between sensitivity and earnings manipulation (path (i)) indicates that executives place a higher expected value on the compensation-based benefits of manipulation (path (iii)) than on the compensation-based penalties associated with the manipulation being discovered and disclosed (path (iv)). This expected value is the sum of the products of the likelihood of the benefits/penalties and their magnitude.

\section{Internal Control Weaknesses, Earnings Manipulation and Penalties}

SOX attempts to mitigate managers' ability to manipulate financial reporting by requiring both management and auditors to evaluate and report on the quality of internal control. ${ }^{3}$ Subsequent research has confirmed the relevance of SOX's focus on internal control, finding a positive relation between the existence of ICWs and subsequent accounting manipulations (Figure 1 path (v)). Ashbaugh-Skaife et al. $(2008,2009)$ and Doyle et al. (2007b) find that firms reporting ICWs have a greater absolute value of discretionary accruals, however Ashbaugh-Skaife et al. (2008) pool Sections 302 and 404 ICWs and find no evidence of a relation to signed accruals. They interpret this to indicate that ICWs give rise to unintentional errors rather than income-increasing manipulations. Ghosh et al. (2010) compare the overall level of manipulation in the pre- and post-SOX eras and find a significant decline.

There are significant penalties to executives for weaknesses in internal control beyond those imposed by the SOX legislation. Reporting ICWs also leads to lower share prices (Ashbaugh-Skaife et al., 2009; Beneish et al., 2008; De Franco et al., 2005; Hammersley et al., 2008; Ogneva et al., 2007) and as a result, reduced managerial equity-related wealth (path (vi)). ICW may weaken the ability of accounting systems to monitor operations, resulting in day-to-day operational difficulties, and thus lower earnings (Feng et al., 2009). In addition, studies of accounting accrual manipulations comparing the pre- and post-SOX eras (Cohen et al., 2008; Jiang et al., 2010) find a reduction but not elimination of earnings manipulation arising from compensation sensitivity, indicating that SOX-related penalties have affected managerial behavior. It also creates significant penalties for the CEOs and CFOs of firms that do not comply (Carter et al., 2009), especially for CFOs, who face significant labor market penalties (Collins et al., 2009). Brown and Lim (2012) also find a decreased strength in the association between earnings and executives' (CEO and CFO) compensation when the firm reports ICW. In extreme cases, executives face criminal penalties in addition to stiff fines and compensation clawbacks. Carter et al. (2009) report an increase in the weight placed on earnings changes as a determinant of executive compensation, and a decrease in the proportion of compensation from salary after SOX, that is larger for CEOs and CFOs than for other executives. In addition, Hoitash et al. (2012) find that disclosure of ICW leads to reductions in CFO total compensation, bonus compensation, and equity compensation, revealing the importance of internal control quality as a non-financial performance measure in the evaluation of CFOs.

\footnotetext{
${ }^{3}$ Section 302 requires that management establish, maintain and regularly evaluate the effectiveness of internal controls. They must report the results of this evaluation and any significant changes in internal controls in both quarterly and annual financial statements. In doing so, managers must report any specific internal control weaknesses that exist. Section 404 requires that auditors independently report on internal control and describe ICW. Section 304 specifies substantial penalties for misreporting, including large fines and imprisonment.
} 
Weaknesses are also associated with audit delays (Ettredge et al. 2006) and higher audit fees (Hogan and Wilkins, 2008; Hoitash et al., 2009; Raghunandan and Rama, 2006), further lowering earnings. Boards of directors are able to initiate an investigation of weaknesses to detect compensation targets being met via manipulation, leading to adjustment of compensation in current and future years to offset these effects (Burks, 2010; Hoitash et al., 2012). Further, given SOX's requirements and responsibilities for audit committees (Srinivasan, 2005) the board may go beyond merely offsetting the manipulation for the purpose of calculating compensation and further penalize the manager, including termination of employment (Burks, 2010; Cheng and Farber, 2008; Collins et al., 2009; Desai et al., 2006; Hennes et al., 2008; Johnstone et al., 2011; Li et al., 2010).

\section{Other Firm Characteristics and Internal Control Weaknesses}

A substantial body of research examines the firm and auditor characteristics associated with the effectiveness of internal control (Figure 1 path (vii)). Ge and McVay (2005) find several factors to be significant, including whether or not the firm is profitable, business complexity, and audit firm size. Krishnan (2005) finds that audit committee independence and financial expertise enhance internal control. Bronson et al. (2006) find that firm size, sales growth and institutional ownership are associated with internal control effectiveness. Doyle et al. (2007a) examine a larger sample and find new factors to be significant including firm age, bankruptcy risk, and restructuring. Ashbaugh-Skaife et al. (2007) expand the analysis to focus on auditor incentives and confirm that audit firm size, institutional ownership and earnings restatements are associated with the likelihood of reporting ICWs. Zhang et al. (2007) find audit committee financial expertise and auditor independence reduce the likelihood of control weaknesses. Hoitash et al. (2009) find that board strength and audit committee experience in accounting and supervision reduce the likelihood of reporting weaknesses.

\section{Compensation Sensitivity and Quality of Internal Control}

In contrast to the extensive research stream investigating the effect of compensation on earnings manipulation, and notwithstanding both the centrality of performance-based ex ante incentives in explaining managerial behavior, and SOX's focus on enhancing internal control to mitigate manipulation, research has not yet investigated whether compensation incentives affect the quality of internal control over financial reporting.

Previous research described above finds a positive relation between compensation sensitivity and subsequent earnings manipulation (Figure 1 path (i)), indicating that managers place a higher expected value on the anticipated benefits of manipulation (path (iii)) than on the possible future penalties arising from potential detection (path (iv). Compensation sensitivity creates incentives to manipulate which may enable managers to tolerate internal control weaknesses in order to maintain the ability to manipulate future earnings. Given that there is a positive relation between control weaknesses and manipulation (path (v)), and absent incremental penalties to internal control weaknesses (i.e. path $(\mathrm{vi})=0$ ), one would expect a positive relation between compensation sensitivity and the likelihood of ICWs.

However, evidence exists showing significant penalties for reporting ICWs (i.e. path (vi) is positive). ICWs are reported concurrently with audited financial statements, leading to reactions by markets and boards of directors. Research has found that firms reporting weaknesses have higher market costs of equity, reducing their equity valuation (Ashbaugh-Skaife et al., 2009; Beneish et al., 2008; Hammersley et al., 2008), and may incur operational costs due to a lack of control (Feng et al., 2009). The expected net effect of the penalties of immediate reporting of ICWs relative to the benefits of manipulation is unclear. Balsam and Jiang (2009) make no prediction of the net impact of these two opposing effects, but find a negative relation between the aggregate sensitivity of top five executives' stock and stock option holdings and ICW reporting. ${ }^{4}$ Consistent with this finding, in the next section we hypothesize that the expected value of penalties for reporting ICWs dominate the anticipated benefits of earnings manipulation, but that the net effect of these incentives depends upon whether their time horizon is short-term or long-term.

\footnotetext{
${ }^{4}$ In a robustness test they aggregate $\mathrm{CEO}$ and $\mathrm{CFO}$ compensation and find similar results. 


\section{Hypothesis $1(\mathrm{H1}): \quad \quad$ Compensation sensitivity time horizon and quality of internal control}

The time horizon of performance-based compensation is expected to be salient in explaining the reporting of SOX- related ICWs. Only three studies examining compensation sensitivity's effect on earnings manipulations (Figure 1 path (i)) address incentive time horizon. Burns and Kedia (2006) argue that the time horizon of an incentive significantly affects its future behavioral effect. We classify each form of compensation as having either a short- or long-term time horizon. In the empirical analysis each form of compensation is examined individually so that the results are not an artifact of this classification, and because the different scales of the forms make aggregation problematic. ${ }^{5}$

Vested options can be exercised at any time, making executive wealth a convex function of stock price. This means that an income-increasing manipulation for an option that is at or close to being 'in the money' increases wealth more than a similar income-decreasing manipulation decreases wealth. This creates an incentive for incomeincreasing accounting manipulation that is greater than for unrestricted equity holdings. Similar convexity in salary and bonus payments that are received immediately would have similar effects. Unrestricted equity holdings can be sold immediately and are classified as short-term time horizon holdings. In contrast, unvested options, restricted equity holdings and long term incentive plans are subject to a waiting period with associated uncertainty concerning price or performance declines or downward adjustment by the board of directors after the reporting of any related ICW (Figure 1 path (vi)), therefore, rational managers discount their value.

Managers weigh the expected value of benefits accruing from the weakness (the likelihood the weakness can be exploited to manipulate earnings times the incremental compensation that would be earned from it) against the expected value of costs of a control weakness (the penalties for public reporting times its probability of detection). While the benefits vary with the time frame of compensation, the penalties do not. For short-term horizon incentives, the net effect is unclear. For long-term horizon incentives the same probability and costs of reporting an ICW exist but are weighed against the future value of incentives from later, more uncertain unvested incentives (Figure 1 path (vi)). Based on this, a negative relation is hypothesized between incentives and ICW reporting.

H1. Long term horizon pay-for-performance incentives (unvested options, restricted equity holdings and long term incentive plans) are negatively related to the likelihood of reporting a material ICW.

\section{Hypothesis 2 (H2): $\quad$ Compensation sensitivity and severity of internal control weaknesses}

Following a classification scheme proposed by Moody's, Doyle et al. (2007a, 2007b) subdivide ICWs by their severity based on their scope of impact. This scheme distinguishes company-level weaknesses (CLWs - which have a pervasive impact and call into question management's ability to prepare financial statements and control the business) from account-specific weaknesses (ASWs - which have a narrow scope and are susceptible to in-depth investigation by auditors, the board of directors or regulators). CLWs include conditions such as an ineffective control environment, an ineffective audit committee, an inadequate internal audit or risk assessment function, and an ineffective financial reporting process (PCAOB Standard No. 2). ${ }^{6}$ ASWs relate to control problems over transactional-level processes or specific account balance, such as inventory, accounts receivable, and legal proceedings (Doss, 2004). None of the empirical studies relating the reporting of weaknesses to stock market values, bonuses, turnover or subsequent labor market costs (Figure 1 path (vi)) compare the effects of CLWs and ASWs.

CLWs are more likely to reflect CEO and CFO behavior since the CEO and CFO set the 'tone at the top', an integral part of the overall control environment. The greater scope of these ICW would better facilitate managerial manipulation (Figure 1 path (v)), making it more likely to reflect the effect of compensation sensitivity.

\footnotetext{
${ }^{5}$ For example, the effect of restricted equity options is calculated based on the effect of a $1 \%$ change in equity price, while ltip_ratio is long-term incentive payouts divided by total compensation grants. Aggregating these into a single long-term incentive measure requires development of a non-arbitrary weighting scheme.

${ }^{6}$ According to PCAOB Standard No.2, company-level controls refer to controls that "might have a pervasive effect on the achievement of many overall objectives of the control criteria," whereas specific controls are those that are "designed to achieve specific objectives of the control criteria."
} 
ASWs are more likely to reflect local business processes, limiting the ability to manipulate and therefore their relation to compensation sensitivity. Offsetting their higher impact, the greater severity of a CLW would make it more susceptible to significant penalties levied by the board of directors and regulators described in the discussion of Figure 1 path (vi). The net effect is unclear. Brown and Lim (2012) examine compensation penalties and find that reporting a CLW offsets any potential positive effect from ROA improvements in addition to a fixed reduction in cash compensation, while ASWs are not associated with elimination of ROA improvement effects on cash compensation. Doyle et al. (2007b) find that CLWs are positively related to accrual manipulation but ASWs are not. Balsam and Jiang (2009) find the effect of CEO and CFO aggregate compensation sensitivity is more salient for company-level than for ASWs. Overall, the effects hypothesized in $\mathrm{H} 1$ are expected to be most salient for CLWs.

H2. The negative relation between long-term compensation sensitivity and reported ICWs will be stronger for company-level control weaknesses than account-specific weaknesses.

\section{EMPIRICAL METHODS}

\section{Sample Selection}

Table 1A summarizes the sample selection process. Executive compensation and management ownership data were obtained for 1,861 firms from Standard and Poor's ExecuComp for the 2004-2006 period. For year-ends after June 15, 2006, ExecuComp significantly revised its reporting of long-term incentive payouts to reflect the new compensation reporting requirements SFAS 123(R), precluding comparison to the 2004-2006 period. One hundred and fifty-eight firms with missing control variable data from Compustat were eliminated. Corporate governance data were then manually collected from Forms 10-K, 8-K, and DEF 14A filed in the sample period, and 18 firms with missing governance data were deleted, yielding a final sample of 1,685 firms. Next, firms with ICW were identified using the Audit Analytics database. Each observation was validated using manually collected SOX 404 auditors' opinions containing references to ICWs in financial reporting in firms' $10-\mathrm{K}, 8-\mathrm{K}$, and 10-Q filings from January 2004 to December 2006. Depending on the firm's fiscal year-end, its first SOX 404 opinion can fall in either fiscal year 2004 or 2005. ${ }^{7}$ The intersection of the data from ExecuComp, Compustat and Audit Analytics with manual validation created a data set of 302 distinct firms for CEOs (140 firms in 2004; 115 firms in 2005; and 47 firms in 2006) and 267 firms for CFOs (124 firms in 2004; 99 firms in 2005; and 44 firms in 2006) with ICW. In the event of more than one disclosure by a firm during the sample period, we retain only the first disclosure. Our control sample consists of 1,383 firms for CEOs (3,352 firm-year observations) and 1,325 firms for CFOs (2,918 firm-year observations) that did not report ICW during the sample period. The final sample contains 3,654 firm-year observations for CEOs and 3,185 firm-year observations for CFOs.

\section{Industry Distribution of Sample}

Table 1B reports the industry distribution of the CEO compensation sample of 302 firms with ICW and the 1,388 control firms based on the Fama-French five-industry classification. The high-technology sector constitutes 25 percent of the firms with ICW, followed by the consumer service sector (23\%), manufacturing (20\%), health care $(5 \%)$, and other industries (27\%). The industry distribution is similar for the control firms.

\footnotetext{
${ }^{7}$ Since SOX404 was effective for accelerated filer firms (market capitalization greater than $\$ 75$ million) in fiscal years ending or after November 15, 2004, an accelerated-filer with a fiscal year ending on or after November 15, 2004 filed its auditor's first SOX 404 opinion in its 2004 fiscal year, while a firm with a fiscal year ending from June 1 through November 14, 2004 was not required to file its first SOX404 audit opinion until its 2005 fiscal year. For firms with fiscal year-ends of January-May, the Compustat data filed "YEARA" value does not align with firms' fiscal year-ends. Therefore, we carefully control and align firms' SOX 404 reports with the respective Compustat in 2004-2006.
} 
Table 1A

Sample Selection - SOX 404 Disclosures of Internal Control Weaknesses (ICWs)

Number of firms in ExecuComp with complete compensation data for 2004-2006 1,861

Less: Firms missing Compustat data

ef firms with ExecuComp and Compustat data for 2004-2006

1,703

Less: Firms missing governance data

Number of firms with Execomp, Compustat and governance data

1,685

Weakness Sample (ICW = 1)

Number of distinct firms that disclosed material weakness(es) in internal control from November 13, 2004 to December 31,2006 (one observation per firm)

\begin{tabular}{lrr} 
& \multicolumn{1}{c}{ CEO } & CFO \\
2004 & 140 & 124 \\
2005 & 115 & 99 \\
Total sample & $3 \underline{47}$ & $\underline{44}$
\end{tabular}

Control Sample $(\mathrm{ICW}=0)$

Number of distinct firms that did not report material weakness(es) in internal control during the period November 13, 2004 to December 31,2006

\begin{tabular}{lll} 
& $\frac{\mathrm{CEO}}{1,383}$ & $\underline{\mathrm{CFO}}$ \\
Firms & 3,325 \\
Firm-observations & 3,352 & 2,918 \\
\hline
\end{tabular}

Table 1B

Distribution of Firms by Industry for CEO sample

\section{Industry}

Consumer products and services

Manufacturing

High-tech

Health care

Others

Total

\begin{tabular}{cr} 
ICW $=1$ & \\
\hline$\underline{\mathrm{N}}$ & $\frac{\%}{23}$ \\
61 & 20 \\
76 & 25 \\
15 & 5 \\
$\underline{80}$ & 27
\end{tabular}

\begin{tabular}{rr} 
NOMW & \\
\hline$\underline{\mathrm{N}}$ & $\frac{\%}{20}$ \\
350 & 25 \\
275 & 20 \\
111 & 8 \\
$\underline{378}$ & 27 \\
1,383 &
\end{tabular}

ICW $=1$ if one or more material weaknesses in internal control reported between November 13, 2004 and December 31, 2006; else 0 (NOMW).

Based on Fama/French 5 industry benchmark portfolios.

\section{Research Design}

The hypothesized (H1) relation between the sensitivity of the CEO's performance-based compensation structure (e.g. aggregate stock options, restricted and unrestricted equity, long-term incentive payouts, and salary plus bonus) and the propensity to disclose ICW is estimated to be the following baseline logistic regression:

$$
\begin{aligned}
I C W_{\mathrm{it}}= & \beta_{0}+\beta_{1} \text { delta_options }_{\mathrm{it}}+\beta_{2} \text { delta_restr }_{\mathrm{it}}+\beta_{3} \text { delta_equity }_{\mathrm{it}}+\beta_{4} \text { ltip_ratio }_{\mathrm{it}}+\beta_{5} \text { delta_salary }_{\mathrm{it}}+\beta_{6} \\
& \text { opt_exer_ratio }_{\mathrm{it}}+\beta_{7} \text { size }_{\mathrm{it}}+\beta_{8} \text { age }+\beta_{9} \text { risk }_{\mathrm{it}}+\beta_{10} \text { mtb }_{\mathrm{it}}+\beta_{11} \text { loss }_{\mathrm{it}}+\beta_{12} \text { lev }_{\mathrm{it}}+\beta_{13} \text { exsale }_{\mathrm{it}}+\beta_{14} \text { seg }_{\mathrm{it}}+\beta_{15} \\
& \text { restruct }_{\mathrm{it}}+\beta_{16} \text { fortrans }_{\mathrm{it}}+\beta_{17} \text { big }_{\mathrm{it}}+\beta_{18} \text { afee }_{\mathrm{it}}+\beta_{19} \text { audch }_{\mathrm{it}}+\beta_{20} \text { ceochair }_{\mathrm{it}}+\beta_{21} \text { bdind }_{\mathrm{it}}+\beta_{22} \text { consum }_{\mathrm{it}}+\beta_{23} \\
& \text { manuf }_{\mathrm{it}}+\beta_{24} \text { hitech }_{\mathrm{it}}+\beta_{25} \text { health }_{\mathrm{it}}+\beta_{26} \text { soxyr }_{\mathrm{it}}+\beta_{27} \text { soxyr }_{\mathrm{it}}+\varepsilon_{\mathrm{it}}
\end{aligned}
$$

where variables are defined below, and $\mathrm{i}$ indicates the firm and $\mathrm{t}$ indicates the year. Firms reporting one or more ICW are only included in the analysis for the first year they report. Firms never reporting an ICW during the sample period (the control sample) are included for all years available. The observations are pooled.

An alternative version of Equation (1) that disaggregates stock options by time horizon (replacing delta_options with delta_vested and delta_unvested) is also tested: 


$$
\begin{aligned}
I C W_{\mathrm{it}}= & \beta_{0}+\beta_{1} \text { delta_vested }_{\mathrm{it}}+\beta_{2} \text { delta_unvested }_{\mathrm{it}}+\beta_{3} \text { delta_restr }_{\mathrm{it}}+\beta_{4} \text { delta_equity }_{\mathrm{it}}+\beta_{5} \text { ltip_ratio }_{\mathrm{it}}+\beta_{6} \\
& \text { delta_salary }_{\mathrm{it}}+\beta_{7} \text { opt_exer_ratio }_{\mathrm{it}}+\beta_{8} \text { size }_{\mathrm{it}}+\beta_{9} \text { age }+\beta_{10} \text { risk }_{\mathrm{it}}+\beta_{11} \text { mtb }_{\mathrm{it}}+\beta_{12} \text { loss }_{\mathrm{it}}+\beta_{13} \text { lev }_{\mathrm{it}}+\beta_{14} \text { exsale }_{\mathrm{it}} \\
& +\beta_{15} \text { seg }_{\mathrm{it}}+\beta_{16} \text { restruct }_{\mathrm{it}}+\beta_{17} \text { fortrans }_{\mathrm{it}}+\beta_{18} \text { big }_{\mathrm{it}}+\beta_{19} \text { afees }_{\mathrm{it}}+\beta_{20} \text { audch }_{\mathrm{it}}+\beta_{21} \text { ceochair }_{\mathrm{it}}+\beta_{22} \text { bdind }_{\mathrm{it}}+ \\
& \beta_{23} \text { consum }_{\mathrm{it}}+\beta_{24} \text { manuf }_{\mathrm{it}}+\beta_{25} \text { hitech }_{\mathrm{it}}+\beta_{26} \text { health }_{\mathrm{it}}+\beta_{27} \text { soxyr }_{\mathrm{it}}+\beta_{28} \text { soxyr }_{\mathrm{it}}+\varepsilon_{\mathrm{it}}
\end{aligned}
$$

The hypothesized relation (H2) between the sensitivity of the CEO's performance-based compensation structure and the propensity to disclose company-level (vs. account-specific) ICW in financial reporting is estimated by classifying control weakness observations as either (1) company-level material weaknesses, or (2) accountspecific material weaknesses (Ashbaugh-Skaife et al., 2007a; Doyle et al., 2007 a, 2007b) and by running the baseline and disaggregated models separately pooled with control firm observations.

All significance levels in the logistic regression analysis are estimated using bootstrapped bias-corrected and accelerated coefficients from logistic regressions (e.g., Efron and Tibshirani, 1993) as follows. A 'resample' of the original sample size was selected from the sample with replacement of observations. For the resample, regression coefficients for the model were estimated. This was repeated 2,000 times to generate a distribution for each coefficient. Efron and Tibshirani (1997), Gong (1986), and Steyerberg et al. (2001) demonstrate that bootstrapping methods substantially reduce the variability of error rate estimates in logistic regression because of their full use of sample information.

Because firms without ICW are included in multiple years, we must account for potential serial correlation when estimating Equations (1) and (2). Goncalves and White (2005) show that bootstrapped estimates are accurate in the presence of serial correlation and heteroskedasticity in the regression setting. In untabulated analysis we adjust standard errors for serial correlation and heteroskedasticity (Froot, 1989), resulting in more conservative standard error estimates and find similar results.

\section{Measures of CEO Pay-Performance Sensitivity}

We follow the approach of Burns and Kedia (2006) to measure the sensitivity of the various components of compensation. To control for potential outliers, the variables are winsorized at the $1 \%$ and $99 \%$ levels. First, option sensitivity is measured using delta_vested and delta_unvested, which are measured as the change in the BlackScholes option value (in \$000s) of the vested and unvested portions, respectively, of a CEO's stock option portfolio for a one percentage point change in stock price. This is calculated using the approach of Core and Guay (2002). These are summed to obtain total option sensitivity (delta_options). Second, the sensitivities of restricted (delta_restr) and unrestricted (delta_equity) equity holdings are defined as the change in the value of these holdings for a one percentage point change in stock price. They are obtained by multiplying the number of shares held by $1 \%$ of the stock price and expressed in $\$ 000$ 's. Third, as in Burns and Kedia (2006), the incentive provided by long-term incentive plans (litip_ratio) is measured as the long-term incentive plan payouts divided by the total compensation, including current year option grants. These are typically based on performance over a three-to-five year period.

Fourth, sensitivity of salary and bonus (delta_salary) is calculated as the ratio of the annual percentage change in salary and bonus to the percentage change in firm net income. This approach provides a different sensitivity measure for each firm for every year and is different from that used in Burns and Kedia (2006), which is common to all firms in the same two-digit SIC industry. Fifth, the ratio of options exercised in the current year to vested options as of year-end (opt_exer_ratio) is included to measure the extent to which managers have already realized profits from option exercises.

\section{Control Variables}

The analysis controls for four types of firm factors found to be associated with ICWs in financial reporting: (1) Financial and stability characteristics, such as firm size (size), age (age), bankruptcy risk (risk), market-to-book (mtb), loss (loss), leverage (lev), and extreme sales growth (exsale) (Ashbaugh-Skaife et al., 2007; Beneish et al., 2008; Doyle et al., 2007a; Klein, 2002;); (2) business complexity, such as number of segments (seg), restructuring (restruct), and foreign transactions (fortrans) (Ashbaug-Skaife et al., 2007; Doyle et al., 2007a); (3) audit quality, such as big-4 auditors (big4), audit fees (afees), and auditor changes (audch) (Ashbaugh-Skaife et al., 2007; Doyle et al., 2007a; Klein, 2002; Krishnan, 2005); (4) Two governance variables are included. Ceochair controls for the 
effect of a CEO serving as the chairman of the board of directors because prior studies provide evidence that CEOs who also serve as chair have a negative impact on board monitoring (Alexander et al., 1993; Dechow et al., 1996). Board independence (bdind) is included because more independent boards reduce the likelihood of accounting fraud (Beasley, 1996) and similarly monitor for ICWs. Industry effects are controlled using Fama and French's fiveindustry classification effects, and year effects are captured using indicator variables for each of the two years after the initial year of mandatory SOX reporting. The definitions for all variables are listed below each table.

\section{RESULTS}

\section{Descriptive Statistics and Univariate Analysis}

Table 2A presents descriptive statistics for compensation sensitivity in the CEO and CFO compensation samples. For all the compensation components except salary, pay-for-performance sensitivities for CEOs are substantial and are higher than for CFOs. Table 2B conducts univariate analyses comparing the characteristics of firms reporting weaknesses (ICWs) to firms with effective controls (NOMW) for the two samples. Firms with weaknesses have lower pay-for-performance sensitivity for all components of compensation. On average, the value of the stock options held by CEOs (CFOs) at firms with ICW changes by $\$ 219,000(\$ 41,870)$, for a $1 \%$ change in stock price composed of $\$ 161,820(\$ 25,320)$ from vested options and $\$ 57,660(\$ 16,550)$ from unvested options. These values are significantly lower than they would be for CEOs and CFOs at firms without weaknesses.

Table 2A

Sample Descriptive statistics

\begin{tabular}{|c|c|c|c|c|c|c|c|c|}
\hline \multirow{3}{*}{ delta_options } & \multicolumn{4}{|c|}{ CEO $(\mathrm{N}=3,654)$} & \multicolumn{4}{|c|}{ CFO $(\mathrm{N}=3,185)$} \\
\hline & Mean & Std.Dev & Min. & Max. & Mean & Std.Dev & Min. & Max. \\
\hline & 354.35 & 553.37 & 0.00 & 3391.18 & 75.69 & 114.66 & 0.00 & 797.08 \\
\hline delta_vest & 260.98 & 443.85 & 0.00 & 2835.29 & 50.33 & 86.02 & 0.00 & 553.30 \\
\hline delta_unvest & 94.75 & 178.19 & 0.00 & 1770.23 & 25.97 & 45.18 & 0.00 & 367.51 \\
\hline delta_equity & 557.99 & 1688.71 & 0.00 & 13319.71 & 29.83 & 57.22 & 0.00 & 475.99 \\
\hline delta_salary & 0.39 & 1.26 & -0.33 & 11.79 & 0.45 & 1.68 & -0.36 & 14.20 \\
\hline opt_exer_ratio & 0.20 & 0.33 & 0.00 & 1.00 & 0.20 & 0.34 & 0.00 & 1.00 \\
\hline delta_restr & 30.31 & 68.28 & 0.00 & 456.53 & 8.26 & 17.01 & 0.00 & 115.30 \\
\hline ltip_ratio x 100 & 2.81 & 9.33 & 0.00 & 59.88 & 2.30 & 8.10 & 0.00 & 54.34 \\
\hline size & 16368.31 & 77604.35 & 20.63 & 1494037.00 & 13736.35 & 66070.09 & 20.63 & 1494037.00 \\
\hline age & 24.60 & 19.11 & 1.00 & 81.00 & 24.50 & 19.09 & 1.00 & 81.00 \\
\hline risk & 197.51 & 2777.07 & -30.82 & 99642.76 & 184.96 & 2610.79 & -30.82 & 99642.76 \\
\hline mtb & 1.98 & 1.28 & 0.65 & 15.65 & 1.98 & 1.30 & 0.65 & 15.65 \\
\hline loss & 0.11 & 0.31 & 0.00 & 1.00 & 0.11 & 0.32 & 0.00 & 1.00 \\
\hline lev & 0.15 & 0.14 & 0.00 & 1.03 & 0.15 & 0.14 & 0.00 & 1.03 \\
\hline exsale & 0.20 & 0.40 & 0.00 & 1.00 & 0.20 & 0.40 & 0.00 & 1.00 \\
\hline seg & 4.88 & 2.97 & 1.00 & 24.00 & 4.87 & 2.95 & 1.00 & 24.00 \\
\hline restruct & 0.30 & 0.46 & 0.00 & 1.00 & 0.30 & 0.46 & 0.00 & 1.00 \\
\hline fortrans & 0.27 & 0.44 & 0.00 & 1.00 & 0.27 & 0.44 & 0.00 & 1.00 \\
\hline big4 & 0.96 & 0.19 & 0.00 & 1.00 & 0.96 & 0.19 & 0.00 & 1.00 \\
\hline afees & 3.79 & 5.88 & 0.09 & 90.20 & 3.61 & 5.34 & 0.092 & 90.20 \\
\hline audch & 0.04 & 0.20 & 0.00 & 1.00 & 0.05 & 0.21 & 0.00 & 1.00 \\
\hline ceochair & 0.54 & 0.50 & 0.00 & 1.00 & 0.54 & 0.50 & 0.00 & 1.00 \\
\hline bdind & 0.78 & 0.11 & 0.27 & 1.22 & 0.78 & 0.11 & 0.27 & 1.22 \\
\hline consum & 0.18 & 0.39 & 0.00 & 1.00 & 0.18 & 0.38 & 0.00 & 1.00 \\
\hline manuf & 0.26 & 0.44 & 0.00 & 1.00 & 0.27 & 0.44 & 0.00 & 1.00 \\
\hline hitech & 0.19 & 0.39 & 0.00 & 1.00 & 0.19 & 0.40 & 0.00 & 1.00 \\
\hline health & 0.08 & 0.27 & 0.00 & 1.00 & 0.08 & 0.27 & 0.00 & 1.00 \\
\hline others & 0.29 & 0.45 & 0.00 & 1.00 & 0.28 & 0.45 & 0.00 & 1.00 \\
\hline
\end{tabular}

All compensation sensitivity measures winsorized at $1 \%$ and $99 \%$.

delta_options $=$ change in the Black-Scholes value of option portfolio for a $1 \%$ change in stock price in $\$ 000 \mathrm{~s}$.

delta_vest $=$ vested delta options in $\$ 000$ s.

delta_unvest $=$ unvested delta_options in $\$ 000$ s.

delta_equity $=$ change in the value of unrestricted equity for a $1 \%$ change in stock price in $\$ 000 \mathrm{~s}$.

delta_salary $=$ Percentage change in salary and bonus/percentage change in NI over previous year.

opt_exer_ratio $=$ Ratio of options exercised in current year/exercisable options as at year-end.

delta_restr $=$ change in the value of restricted equity for a $1 \%$ change in stock price in $\$ 000$ s. 
ltip_ratio = Cumulative long-term incentive plan payouts/total compensation including grants.

size $=$ Total Assets at beginning of year in \$millions.

age $=$ Number of years the firm has CRSP data.

risk $=$ Altman's Z-Score where Z-Score $=3.3 *$ (operating income after depreciation/assets $)+1.2 *(($ current asset-current liability $) /$ assets $)+$ (sales/assets) $+0.6 *(($ shares outstanding*price_fiscyr $) /($ total long term debt $))+1.4 *($ retained earnings/assets $)=$ if long-term debt $>0$, else Z-Score $=3.3 *$ (operating income after depreciation/assets) $+1.2 *(($ current asset-current liability $) /$ assets $)+$ (sales/assets)+1.4*(retained earnings/assets) (negatively related to bankruptcy risk)

$\mathrm{mtb}=$ (assets - book value of common equity + market value of common equity)/assets at beginning of year.

loss $=1$ if earnings before extraordinary items in years $t$ and $t-1$ sum to less than zero, and 0 otherwise.

lev $=$ Current liabilities plus long-term debt divided by total assets.

exsale $=1$ if top quintile industry-adjusted sales growth over prior year, and 0 otherwise.

seg $=$ Number of business segments + geographic segments in year $\mathrm{t}$.

restruct $=1$ if restructure charge is not equal to zero for any year in 2001-2003, and 0 otherwise.

fortrans $=1$ if firm has a non-zero foreign transaction in year $\mathrm{t}$, and 0 otherwise.

big $4=1$ if auditor is a Big 4 firm, and 0 otherwise.

afees $=$ Annual audit fees in \$millions.

audch $=1$ if there is an auditor change in the previous or current year, and 0 otherwise.

ceochair $=1$ if the CEO also a chairman of the board of directors, and 0 otherwise.

bdind $=$ Proportion of board members who are independent.

consum, manuf, hitech, health = 1 based on Fama/French 5 industry benchmark portfolios (baseline category others).

Table 2B

Comparison of Firms Reporting Internal Control Weaknesses with Other Firms

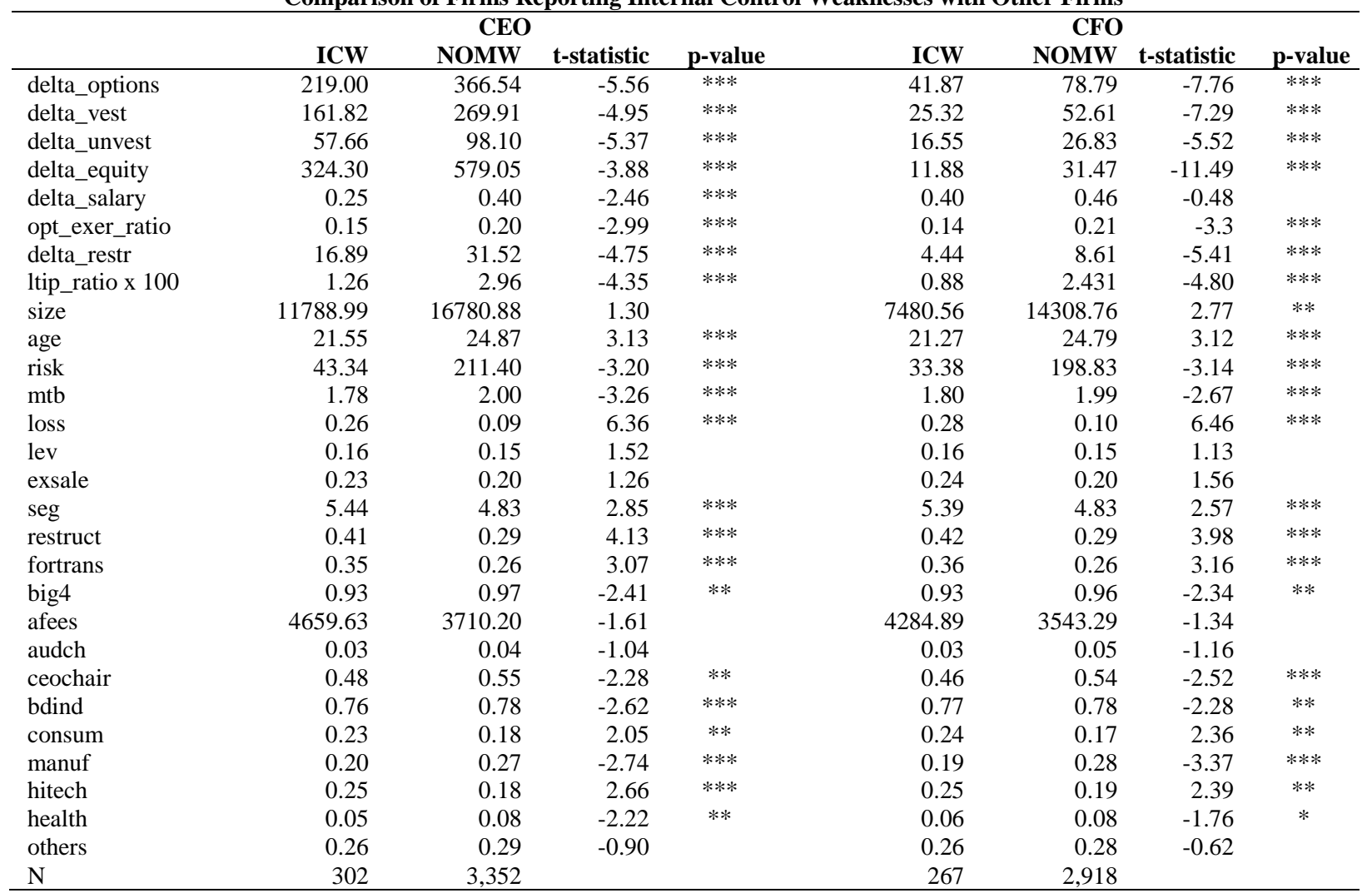

p-values are based on two-tailed tests: * significant at 10\%; ** significant at 5\%; *** significant at $1 \%$.

ICW $=1$ if one or more material weaknesses in internal control reported between November 13,2004 and December 31, 2006; else 0 (NOMW).

The mean sensitivity of restricted equity for CEOs for firms with weaknesses is $\$ 16,890$ and is significantly lower than the $\$ 31,520$ for control firms. Similarly, long-term incentive plan payouts for CEOs at firms with ICW are lower than NOMW. CEO salary plus bonus sensitivity to change in net income for firms with weaknesses is 25 percent lower than the 40 percent for CEOS at control firms, while it is 40 percent for CFOs at firms with 
weaknesses and 46 percent for CFOs at control firms. The mean sensitivity of unrestricted equity holdings for CEOs (CFOs) at firms with ICW is $\$ 324,300$ ( $\$ 11,880)$, which is lower than the level at firms without weaknesses of $\$ 579,050$ ( $\$ 31,470)$. Finally, the proportion of options exercised during the year to those vested at year-end is 15 percent (14 percent), lower than the mean of 20 percent (21 percent) at control firms.

We also find that, when compared to firms with effective controls, firms with ICW are smaller, younger, have a higher risk, a lower market-to-book ratio, report higher losses, are more complex (as measured by having more segments, more restructuring and foreign transactions). In addition, firms with ICW are less likely to be clients of Big 4 auditors, report higher audit fees, and are less likely to have the CEO serving as the chairman of the board as well as being less likely to have independent board members. This is consistent with findings in prior research.

The compensation components were analyzed for correlation. In general, the incentives of the equity and option components of compensation are significantly positively correlated, while the incentives provided by salary and bonus and long term incentive plan payouts are less correlated. None of the correlations for variables included simultaneously are above 0.56 , and the highest variance inflation factor (VIF) in our regressions is 4.9 , which is well below the suggested threshold of 10 (Gujarati, 1995; Marquandt, 1980). Our examination of the standard errors and size of the coefficients also shows that they are not sensitive to the inclusion or exclusion of the highly correlated variables, indicating multicollinearity is unlikely to be problematic (Hosmer and Lemeshow, 1989).

\section{H1 Results: CEO/CFO Compensation Sensitivity and Control Weaknesses}

Table 3 presents the results of a logistic regression analysis estimating the effect of sensitivity of several components of CEO/CFO compensation on the disclosure of at least one ICW. The models are effective with a significant model chi-square value $(\mathrm{p}<0.01)$. The pseudo $\mathrm{R}^{2}$ ranges from 0.18 to 0.20 . The baseline aggregate options model from Equation (1) in models (1) and (3) indicates that option sensitivity is negative for CFOs $(\mathrm{p}<0.05)$ but not for CEOs. The results for the disaggregated options model from Equation (2) in models (2) and (4) indicate that unvested options are negatively related to control weaknesses but vested options are not, for both CEOs and CFOs. This confirms the appropriateness of disaggregating compensation by time horizon. The coefficient for long term incentive plan payouts sensitivity is also significantly negative for both CEOs and CFOs. Restricted stock holdings of CEOs are marginally negatively associated with weaknesses in model (1).

None of the short-term incentives are significant for CEOs, but unrestricted equity sensitivity is negatively associated with ICW for CFOs. This suggests that CFOs may be affected by their equity holdings differently from CEOs. Table $2 \mathrm{~A}$ indicates that mean CFO sensitivity to unrestricted equity holdings is only $5 \%$ of mean CEO unrestricted equity holdings (29.83/557.99). CFOs unrestricted equity sensitivity is only $40 \%$ of that for their options holdings, as compared to $157 \%$ for CEOs. This divergence between the two roles is much greater than the sensitivity of other forms of compensation. This may have implications for market signalling. CEOs and CFOs are generally expected to hold significant amounts of wealth in the form of their firm's stock. Insider stock sales are interpreted as a signal of the firm's future prospects; liquidation of a substantial proportion of their holdings can have a significant impact on stock price. No similar interpretation is associated with sales arising from stock option exercises. Given the CFO's relatively low level of benefit from an equity sale relative to the information communicated to the market and the costs that this would lead to for their superior, the CEO, who has much larger holdings, they may choose to act in the interests of the CEO for job security and reputational reasons and not sell equity opportunistically (Feng et al., 2011). There is some prior empirical evidence that the effect of unrestricted equity holdings on earnings quality is consistent with long- rather than short-term horizon sensitivity. Burns and Kedia (2006) find vested options to be the only element of compensation structure associated with subsequent restatements, with other forms of compensation, including unrestricted equity, having insignificant effects. Cohen et al. (2008) examine abnormal accruals in the pre- and post-SOX eras. ${ }^{8}$ They find that vested options are unrelated to accrual manipulation, while unvested options and equity are positively related to accrual manipulation in both the pre- and post-SOX eras. This evidence suggests CFOs are motivated by their relatively small unrestricted equity holdings to act with a long-term holding horizon.

\footnotetext{
${ }^{8}$ Cohen et al.'s (2008) measure of options is the proportion of the firm owned by the CEO and CFO, rather than the value arising from those options from a one percent change in firm value (Burns and Kedia, 2006) or the ratio of option value to salary compensation (Efendi et al., 2007).
} 
Table 3

CEO/CFO Performance-based Compensation and Reporting of Internal Control Weaknesses (H1)

\begin{tabular}{|c|c|c|c|c|c|c|c|c|c|c|}
\hline \multirow{5}{*}{$\begin{array}{l}\text { delta_options } \\
\text { delta_vest } \\
\text { delta_unvest }\end{array}$} & \multirow{3}{*}{$\begin{array}{c}\text { Time Horizon } \\
\text { ST/LT }\end{array}$} & \multirow{3}{*}{$\begin{array}{c}\text { Expected Sign } \\
-\end{array}$} & \multicolumn{4}{|c|}{ CEO } & \multicolumn{4}{|c|}{ CFO } \\
\hline & & & (1) & & (2) & & (3) & & (4) & \\
\hline & & & -0.27 & & & & -3.28 & ** & & \\
\hline & ST & none & & & 0.05 & & & & -2.41 & \\
\hline & $\mathrm{LT}$ & - & & & -1.48 & $* *$ & & & -5.43 & $*$ \\
\hline delta_equity & ST & none & -0.07 & & -0.07 & & -6.40 & $* * *$ & -6.51 & $* * *$ \\
\hline delta_salary & ST & none & -0.01 & & -0.01 & & 0.02 & & 0.02 & \\
\hline opt_exer_ratio & ST & none & -0.28 & & -0.27 & & -0.25 & & -0.24 & \\
\hline delta_restr & LT & - & -2.57 & * & -2.33 & & -7.88 & & -6.63 & \\
\hline ltip_ratio & LT & - & -2.36 & $* *$ & -2.32 & $* *$ & -3.17 & $* *$ & -3.18 & $* *$ \\
\hline ln size & & & -0.63 & $* * *$ & -0.63 & $* * *$ & -0.58 & $* * *$ & -0.58 & $* * *$ \\
\hline ln age & & & -0.06 & & -0.06 & & -0.08 & & -0.09 & \\
\hline risk & & & -1.23 & **** & -1.25 & $* * *$ & -1.65 & $* * *$ & -1.67 & $* * *$ \\
\hline $\mathrm{mtb}$ & & & -0.23 & $* * *$ & -0.21 & $* * *$ & -0.17 & $* *$ & -0.17 & $* *$ \\
\hline loss & & & 0.48 & $* *$ & 0.49 & ** & 0.49 & ** & 0.49 & $* *$ \\
\hline lev & & & 0.86 & & 0.85 & & 0.88 & & 0.88 & \\
\hline exsale & & & 0.39 & $* *$ & 0.38 & $* *$ & 0.44 & $* *$ & 0.44 & $* *$ \\
\hline seg & & & 0.03 & & 0.03 & & 0.04 & & 0.04 & \\
\hline restruct & & & 0.17 & & 0.18 & & 0.19 & & 0.19 & \\
\hline fortrans & & & 0.14 & & 0.15 & & 0.23 & & 0.23 & \\
\hline big4 & & & -0.72 & $* *$ & -0.70 & $* *$ & -0.73 & $* *$ & -0.74 & $* *$ \\
\hline afees & & & 0.95 & $* * *$ & 0.95 & $* * *$ & 0.95 & $* * *$ & 0.96 & $* * *$ \\
\hline audch & & & -0.51 & & -0.50 & & -0.60 & $*$ & -0.59 & $*$ \\
\hline ceochair & & & 0.01 & & 0.01 & & -0.06 & & -0.06 & \\
\hline bdind & & & -1.22 & $* *$ & -1.24 & ** & -0.86 & & -0.85 & \\
\hline consum & & & -0.16 & & -0.18 & & -0.12 & & -0.13 & \\
\hline manuf & & & -0.87 & $* * *$ & -0.88 & $* * *$ & -1.02 & $* * *$ & -1.03 & $* * *$ \\
\hline hitech & & & -0.60 & $* * *$ & -0.61 & $* * *$ & -0.68 & $* * *$ & -0.69 & $* * *$ \\
\hline health & & & -0.96 & $* * *$ & -0.96 & $* * *$ & -0.89 & $* * *$ & -0.89 & $* * *$ \\
\hline soxyr2 & & & -1.09 & $* * *$ & -1.10 & $* * *$ & -1.08 & $* * *$ & -1.09 & $* * *$ \\
\hline soxyr3 & & & -1.59 & $* * *$ & -1.63 & $* * *$ & -1.64 & $* * *$ & -1.67 & $* * *$ \\
\hline intercept & & & -8.52 & $* * *$ & -8.62 & $* * *$ & -9.04 & $* * *$ & -9.10 & $* * *$ \\
\hline Material weaknesses & & & 302 & & 302 & & 267 & & 267 & \\
\hline Total observations & & & 3,654 & & 3,654 & & 3185 & & 3185 & \\
\hline Wald $\mathrm{chi}^{2}$ & & & 306.43 & $* * *$ & 316.18 & $* * *$ & 262.75 & $* * *$ & 265.89 & $* * *$ \\
\hline Pseudo $\mathrm{R}^{2}$ & & & 0.18 & & 0.19 & & 0.20 & & 0.20 & \\
\hline
\end{tabular}

p-values are based on two-tailed tests: * significant at 10\%; ** significant at 5\%; *** significant at $1 \%$.

All significance levels are calculated using bootstrapped bias-corrected and accelerated confidence intervals based on 2,000 resamples (Efron and Tibshirani, 1993). Substantially similar results are obtained by adjusting standard errors for intrafirm correlation (Froot, 1989) since firms without weaknesses are included for multiple years.

Dependent variable ICW = 1 if internal control weakness reported; else zero.

In size $=$ Natural logarithm of assets at beginning of year in \$millions.

ln age $=$ Natural logarithm of the number of years the firm has CRSP data.

soxyr2 $=1$ if second year of SOX regime reporting (i.e. year-end from Nov. 15, 2005 to Nov. 14, 2006), 0 otherwise;

soxyr $3=1$ if third year, 0 otherwise. Other variables are described in Table $2 \mathrm{~A}$ 
CEO/CFO Performance-based Compensation and Severity of Internal Control Weaknesses (H2)

\begin{tabular}{|c|c|c|c|c|c|c|c|c|}
\hline \multirow[b]{3}{*}{ Variable (exp'd sign) } & \multicolumn{4}{|c|}{ CEO } & \multicolumn{4}{|c|}{ CFO } \\
\hline & \multicolumn{2}{|c|}{ Company-Level } & \multicolumn{2}{|c|}{ Account-Specific } & \multicolumn{2}{|c|}{ Company-Level } & \multicolumn{2}{|c|}{ Account-Specific } \\
\hline & (1) & (2) & (3) & (4) & (5) & (6) & (7) & $(8)$ \\
\hline delta_options (-) & $-0.62 * *$ & & -0.14 & & -2.76 & & $-3.76 * *$ & \\
\hline delta_vest (none) & & -0.24 & & 0.16 & & 0.32 & & -4.69 \\
\hline delta_unvest (-) & & -2.33 & & -1.20 & & $-11.65^{* *}$ & & -2.73 \\
\hline delta_equity (none) & -0.02 & -0.03 & -0.11 & -0.11 & $-20.61 * * *$ & $-21.34 * * *$ & -3.44 & -3.27 \\
\hline delta salary (none) & -0.06 & -0.06 & 0.01 & 0.01 & -0.03 & -0.02 & 0.04 & 0.04 \\
\hline opt_exer_ratio (none) & $-0.61 *$ & -0.61 & -0.09 & -0.08 & -0.36 & -0.34 & -0.15 & -0.16 \\
\hline delta restr (-) & -5.24 & -4.87 & -1.62 & -1.46 & $-29.95 * *$ & $-27.83 * *$ & -0.88 & -0.37 \\
\hline ltip_ratio (-) & -2.46 & -2.37 & -2.37 & -2.35 & $-5.37 * * *$ & $-5.33 * * *$ & -2.48 & -2.49 \\
\hline ln size & $-0.82 * * *$ & $-0.81 * * *$ & $-0.57 * * *$ & $-0.56 * * *$ & $-0.68 * * *$ & $-0.67 * * *$ & $-0.55 * * *$ & $-0.55 * * *$ \\
\hline ln age & 0.05 & 0.05 & -0.11 & -0.11 & 0.09 & 0.07 & -0.17 & -0.17 \\
\hline risk & $-8.96 * * *$ & $-9.23 * * *$ & $-0.61 * *$ & $-0.62 * *$ & $-10.25 * * *$ & $-10.71 * * *$ & -0.91 & -0.90 \\
\hline $\mathrm{mtb}$ & -0.17 & -0.15 & $-0.26 * *$ & $-0.24 * * *$ & -0.11 & -0.09 & $-0.20 * *$ & $-0.20 * *$ \\
\hline loss & 0.32 & 0.34 & $0.59 * * *$ & $0.60 * *$ & 0.38 & 0.40 & $0.57 * *$ & $0.57 * *$ \\
\hline lev & 0.49 & 0.47 & 0.91 & 0.91 & 0.35 & 0.39 & 0.98 & 0.98 \\
\hline exsale & 0.29 & 0.28 & $0.47 * *$ & $0.46^{* * *}$ & 0.35 & 0.35 & $0.50 * *$ & $0.50 * *$ \\
\hline seg & $0.07 *$ & 0.07 & 0.03 & 0.03 & 0.04 & 0.04 & 0.05 & 0.05 \\
\hline restruct & 0.10 & 0.11 & 0.18 & 0.19 & 0.21 & 0.22 & 0.15 & 0.14 \\
\hline fortrans & $0.44 * *$ & $0.46^{*}$ & -0.09 & -0.08 & $0.44 *$ & $0.47 *$ & 0.07 & 0.07 \\
\hline big4 & $-0.81 * *$ & -0.80 & $-0.68 * *$ & $-0.66^{*}$ & -0.78 & -0.77 & $-0.79 * *$ & $-0.80 * *$ \\
\hline afees & $1.33^{* * *}$ & $1.33 * * *$ & $0.81 * * *$ & $0.81 * * *$ & $1.26 * * *$ & $1.27 * * *$ & $0.86 * * *$ & $0.86^{* * * *}$ \\
\hline audch & $-1.86^{*}$ & $-1.86 * * *$ & -0.03 & -0.02 & $-1.83 * * *$ & $-1.79 * * *$ & -0.17 & -0.17 \\
\hline ceochair & -0.01 & -0.02 & 0.01 & 0.01 & -0.09 & -0.11 & -0.02 & -0.02 \\
\hline bdind & -1.58 & -1.57 & -0.97 & -1.00 & -0.93 & -0.93 & -0.68 & -0.69 \\
\hline consum & -0.52 & -0.53 & -0.06 & -0.07 & -0.38 & -0.42 & -0.05 & -0.05 \\
\hline manuf & $-0.74 * *$ & $-0.76^{* * *}$ & $-0.95 * * *$ & $-0.96 * * *$ & $-0.80 * *$ & $-0.84 * *$ & $-1.16^{* * *}$ & $-1.15^{* * * *}$ \\
\hline hitech & -0.22 & -0.23 & $-0.93 * * *$ & $-0.93 * * *$ & -0.36 & -0.40 & $-1.02 * * *$ & $-1.01 * * *$ \\
\hline health & -0.68 & -0.67 & $-1.07 * * *$ & $-1.07 * * *$ & -0.69 & -0.68 & $-0.98 * * *$ & $-0.98 * * *$ \\
\hline soxyr2 2 & -0.22 & -0.24 & $-1.66^{* * *}$ & $-1.67 * * *$ & -0.18 & -0.20 & $-1.69 * * *$ & $-1.69 * * *$ \\
\hline soxyr3 & $-0.56 * *$ & $-0.61 * *$ & $-2.49 * * *$ & $-2.53 * * *$ & $-0.59 * *$ & $-0.68 * *$ & $-2.56 * * *$ & $-2.56 * * *$ \\
\hline intercept & $-14.24 * * *$ & $-14.41 * * *$ & $-7.33 * * *$ & $-7.38 * * *$ & $-14.45^{* * *}$ & $-14.61 * * *$ & $-8.11^{* * *}$ & $-8.11 * * *$ \\
\hline Material weaknesses & 109 & 109 & 193 & 193 & 98 & 98 & 169 & 169 \\
\hline Total observations & 3,461 & 3461 & 3543 & 3543 & 3016 & 3016 & 3087 & 3087 \\
\hline Wald chi2 & $128.13 * * *$ & $128.75 * * *$ & $231.36^{* * *}$ & $248.11 * * *$ & $111.85^{* * *}$ & $114.37 * * *$ & $210.21 * * *$ & $211.68 * * *$ \\
\hline Pseudo R2 & 0.17 & 0.17 & 0.20 & 0.21 & 0.18 & 0.18 & 0.23 & 0.23 \\
\hline
\end{tabular}


These results indicate that firms with higher long-term pay-for-performance are less likely to report ICWs. In contrast, short-term incentives such as vested options (salary, bonus and current exercise of options) are unrelated to the disclosure of an ICW. These findings provide support for $\mathrm{H} 1$ and suggest that time horizon is a critical factor in evaluating how compensation scheme incentives affect managers' choices concerning the strength of systems of internal control.

This may provide insight into the conflicting findings in prior research. Burns and Kedia (2006) find a positive relation between vested options (short-term incentives) and accounting restatements in the pre-SOX 19942001 period while Armstrong et al. (2010) find no relation between the aggregate of vested options, unvested options, restricted equity and unrestricted equity (the sum of short- and long-term incentives), and restatements in the 2001-2005 period using similar methods, and a negative relation using propensity score matching. If short-term and long-term incentives have different effects, a change in their mix over time may explain different findings in the pre-SOX period.

\section{H2 Results: CEO/CFO Compensation Sensitivity and Severity of Control Weaknesses (H2)}

In Table 4, the analysis is refined by investigating whether the results found for $\mathrm{H} 1$ are driven by companylevel weaknesses due to their more severe nature, as hypothesized in H2. For the CEO sample the separation of weaknesses (see models (2) and (4)) into two smaller control-severity samples reduces the power of the analysis, eliminating significance of the disaggregated coefficients in model (2). The significant negative coefficient for aggregate option sensitivity in model (1) appears to arise from unvested options. The latter's larger coefficient relative to model (3) (-2.33 vs. -1.20$)$ suggests that compensation sensitivity may have a greater effect on companylevel weaknesses than account-specific weaknesses, consistent with $\mathrm{H} 2$.

For the CFO sample, separation of weaknesses into models (6) and (8) allows a stronger pattern of relations between sensitivity and control weaknesses to become apparent. The significant relation between unvested option sensitivity and weaknesses seen in Table 3 model (4) is driven by company-level weaknesses: its coefficient in the company-level regression (-11.65) is four times that in the account-specific weaknesses regression $(-2.73)$. The separation makes salient the impact of restricted equity holdings on company-level weaknesses $(-27.83)$ relative to account-specific weaknesses (-0.37), and highlights company-level weaknesses as the driver of effects for unrestricted equity (-21.34 vs. -3.27 for account-specific weaknesses). Finally, the effect of long-term incentive plan payouts is significant for company-level weaknesses (-5.33) but not account-specific weaknesses (-2.49).

These findings for CEOs and CFOs occur despite the loss in power arising from separation of the samples by severity of weaknesses. This evidence provides consistent though limited support for H2: long-term incentives are more strongly related to the likelihood of reporting company-level weaknesses than account-specific weaknesses. This relation is clearer with CFOs, who are primarily responsible for the processes generating financial information and the financial information reported by the firm.

These findings supplement recent evidence of improvements in earnings quality in the post-SOX era. They indicate that the incentives provided to CEOs and CFOs by unvested options and long term incentive plans reduce the likelihood of reporting one or more ICWs in the SOX regime. CFOs holdings of unrestricted equity also reduce the likelihood of reporting company-level weaknesses. This greater scope of impact of compensation on CFOs may occur because, relative to other executives, CFO efforts in fulfilling their fiduciary responsibilities are likely to be the most important determinant of financial reporting quality (Indjejikian and Matejka, 2009; Mian, 2001). Geiger and North (2006) find that discretionary accruals decrease significantly following the appointment of a new CFO, but not the concurrent appointment of a new CEO. Previous research also underscores the importance of CFO qualifications in improving internal controls and financial reporting quality (Aier et al., 2005; Li et al., 2010). The current findings suggest that incentives to avoid reporting control weaknesses outweigh those rewarding financial performance, motivating CFOs to perform their fiduciary responsibilities relating to financial reporting.

Coefficients for the control variables are generally in the predicted directions and are similar to the inferences from the univariate analysis. In Tables 3 and 4, we find that firms reporting ICWs are more likely to be small, have lower market-to-book ratios, report more losses, leverage and extreme sales, and have more segments 
and foreign transactions. They are less likely to be clients of Big 4 auditors, report higher audit fees and restate current or future earnings, but less likely to change auditors and less likely to have independent board members. ${ }^{9}$

\section{Endogeneity}

To investigate the possibility that current year compensation sensitivity is an outcome rather than a cause of current year internal control levels (i.e., that reporting of ICW leads to lower current year compensation sensitivity), for each sensitivity variable ${ }^{10}$ found significant in the results we identified the current-year component that might be adjusted in response to current-year reporting of ICW (i.e., the potentially endogenous portion of each). To evaluate whether internal control reporting is related to these potentially endogenous components the following two-step procedure was performed (analysis not tabulated). A first stage model was created of determinants of reporting ICWs using variables identified in prior research examining ICWs (Doyle et al., 2007a, 2007b) and audit governance (Klein, 2002), and used to calculate an Inverse Mills Ratio (IMR) of the likelihood of a firm reporting an ICW for each observation. The second stage adds the IMR for control weaknesses to regressions predicting the potentially endogenous components, one for each type of compensation sensitivity. Given the negative coefficients found in the Tables 3 and 4, a negative IMR coefficient would indicate that the likelihood of reporting an ICW is negatively related to that component, and therefore endogeneity may be driving the results found. However, the IMR coefficient was not significantly negative in any of the second stage models, indicating that reporting ICWs does not lead to a reduction in current-year compensation sensitivity, i.e., endogeneity is not driving the relations found.

\section{Further Analysis for Robustness of Results}

To assess the robustness of our results to alternative models, samples and methods for measuring our variables, the following analyses were performed (results not tabulated)

\section{Alternative Model - Change in Effects Over Time}

To investigate whether the results are sensitive to the time available for a firm to fix their internal control problems, a dummy variable was created for reports after the initial year. The variable was substituted for the soxyr 2 and soxyr3 dummy variables, and interaction terms of the variable with each of the compensation variables were added to equation (2). None of the interaction terms were significant for CEOs or CFOs.

\section{Alternative Samples}

The period of the analysis is limited to 2004 to 2006 because ExecuComp revised its reporting of long-term incentive payouts in 2007, making it infeasible to perform the reported analyses in 2007. However, analysis of other components of compensation (i.e. options and equity holdings) using the 2007 data provides support for the two hypotheses $(\mathrm{p}<0.05)$.

The control weakness sample used in the analyses only includes firms reporting weaknesses under SOX Section 404. To test the generalizability of our results, we considered control weaknesses reported by nonaccelerated filers under Section $302^{11}$ for fiscal years ending before November 15, 2004, the effective date of Section 404. The results are consistent with, but weaker than, those reported $(\mathrm{p}<0.10)$.

The control sample of firms not reporting weaknesses includes a firm for each year of the three-year sample period, thereby introducing serial correlation. The tests in Tables 3 and 4 correct for this correlation across observations using robust standard errors. As alternative test, potential serial correlation in variables across the three

\footnotetext{
${ }^{9}$ Our results continue to hold when we control for firms that have restated earnings during the sample period.

${ }^{10}$ Unvested options are reduced as options vest during the year but this occurs under the terms of existing contracts, making it exogenous, i.e., not affected by the reporting of control weaknesses. Restricted equity grants that vest during the year are similarly exogenous.

${ }^{11}$ As noted in Ashbaugh-Skaife et al., (2008) and Doyle et al., (2007b), Section 302's rules are less clear, requiring less rigorous assessments of controls compared to Section 404. This may have led to the weaker current findings.
} 
years in the control sample was removed by retaining only the first occurrence of a control firm in the analysis. This yielded similar results.

The analysis reported in Tables 3 and 4 only consider the first year a firm reports ICW. The results are robust to inclusion of observations where firms reported weaknesses in subsequent years (CEO=406, $C F O=360$ ).

\section{Alternative Measures of Severity of ICW and Explanatory Variables}

The analysis was performed using the number of control weaknesses reported as the dependent variable. This variable takes on one of three values: 0,1 , and 2 for all instances where the number of weaknesses is greater than one. The results provide support for $\mathrm{H} 1$.

\section{Compensation Sensitivity and Remediation of Internal Control Weaknesses}

Moody's has stated that the existence of ongoing internal control problems can trigger negative rating action against the firm (Moody's, 2006), emphasizing the need for the remediation of internal control deficiencies to restore confidence in the firm's financial reporting. The timely remediation of ICWs also reflects the efficacy of the corporate governance mechanism (Goh, 2009; Johnstone et al., 2011). We conducted a preliminary analysis (untabulated) of the association between remediation and compensation incentives. For the CEO (CFO) sub-sample, 140 (124) firms that reported ICW in 2004, 91 (80) firms remediated the weaknesses in 2005 and 33 (31) in 2006. For the 115 (99) firms reporting ICW in 2005, 98 (83) firms adopted prompt remediation measures in 2006. We compared firms that fully remediate control weaknesses immediately in the subsequent year to a control group that remediate within two years (the maximum within the sample period) or do not remediate. As an alternative, the control group was also narrowed to include only firms that did not remediate during the period. We found support for the impact of long-term CFO incentive compensation (i.e. equity holdings) on remediation. However, due to the relatively small sample size, the power of the test is likely to be low.

\section{CONCLUSION AND IMPLICATIONS}

This study examines how the level and time horizon of sensitivity for different types of performance-based CEO and CFO compensation affect the likelihood of reporting material weaknesses in internal control required by SOX. The study finds that long-term incentives, including unvested options, and long term incentive plans, are negatively associated with the reporting of ICWs. In contrast, there is evidence that vested CEO options are positively related to ICW reporting, while other short-term incentives are unrelated to ICW reporting, with the exception of unrestricted equity holdings for CFOs only. This exception may be an artifact of the small value of these holdings relative to other forms of compensation and holdings of the CEO, which render them long-term holdings for the purpose of market signalling. These relations hold after controlling for determinants of ICWs identified in prior research. The results provide evidence that time horizon is an important factor in understanding the impact of incentives. They also indicate that incentives to comply with SOX go beyond the financial and criminal penalties specified in the legislation to include CEO and CFO compensation arrangements within the firm.

These effects vary with the severity of control weaknesses, with company-level weaknesses more strongly negatively related to compensation sensitivity than account-specific weaknesses. Unvested option sensitivity is associated with company-level but not account-specific weaknesses for both CEOs and CFOs. Restricted and unrestricted equity holdings and long term incentive plan payments are also related to company-level weaknesses but not account-specific weaknesses for CFOs.

This study has several limitations. First, we use data from SOX 404 internal control reports by focusing on firm-years with both CEO and CFO compensation data from ExecuComp, which consists of fairly large firms. Using accelerated filers that disclose control weaknesses limits the generalizability of the results. In addition, CFOs are only included in the ExecuComp data, and this sample, if they are among the top five highest paid executives of the firm. To the extent that CFO pay reflects their importance within a firm, the results may not generalize regarding firms whose CFOs are not among the five highest paid executives. Third, the statistical power of the various tests performed may be low due to the small sample size. Fourth, it is possible that the results are an artifact of 
unobserved factors that affect the relation between internal control quality and performance-based compensation. Finally, given that audit failures are possible for SOX internal control reporting, to the extent that managers are able to hide weaknesses from the auditors, our measure of internal control quality may not include all firms with ICWs.

These findings have significant implications for boards of directors, managers, auditors, regulators and researchers. Managers' responses to SOX requirements are moving in the direction hoped for by regulators, but only long-term incentives are related to internal control quality. Individual firms' boards of directors and managers may want to consider whether long-term share value-based incentives and short-term negative incentives for SOX violations are sufficient to offset incentives to weaken controls in order to manipulate performance, and may also evaluate the penalties for company-level weaknesses relative to account-specific weaknesses. Auditors can use these findings to inform their assessment of control environment risk at their clients. Regulators may find these results useful in assessing the effects of the Sarbanes-Oxley Act and considering whether and how the level of internal control reporting should be changed in the future. For researchers, these findings provide the first evidence concerning how the time horizon of formal ex ante performance-based compensation incentives affects the quality of internal control in the SOX 404 era. The stronger effects of restricted and unrestricted equity holdings for CFOs relative to CEOs contributes to the ongoing debate on the relative importance of the compensation structure of these two key executives, and suggests that for two forms of compensation, CFO compensation is more salient in explaining internal control quality. The findings extend research indicating that control weaknesses of differing severity have different causes (Doyle et al., 2007a) to address the critical role of compensation structure.

\section{AUTHOR INFORMATION}

Kevin Kobelsky, Ph.D., College of Business, University of Michigan-Dearborn, 4901 Evergreen Road, Dearborn, MI 48126, USA. E-mail: kobelsky@umich.edu (Corresponding author)

Jee-Hae Lim, Ph.D., School of Accounting and Finance, University of Waterloo, 100 University Avenue, Waterloo, ON N2L 3G1, Canada.

Ranjini Jha, Ph.D., School of Accounting and Finance, University of Waterloo, 100 University Avenue, Waterloo, ON N2L 3G1, Canada

\section{REFERENCES}

1. Aier, J., Comprix, J., Gunlock, M., Lee, D. 2005. The financial expertise of CFOs and accounting restatements. Accounting Horizons 19: 123-135.

2. Alexander, J., Fennell, M., Halpern, M. 1993. Leadership instability in hospitals: the influence of boardCEO relations and organization growth and decline. Administrative Science Quarterly 38: 74-99.

3. Armstrong, C., Jagolinzer, A., Larcker, D. 2010. Chief executive officer equity incentives and accounting irregularities. Journal of Accounting Research 48 (2): 225-271.

4. Ashbaugh-Skaife, H., Collins, D., Kinney, W. 2007. The discovery and reporting of internal control deficiencies prior to SOX-mandated audits. Journal of Accounting and Economics 44: 166-192.

5. Ashbaugh-Skaife, H., Collins, D., Kinney, W., LaFond, R. 2008. The effect of SOX internal control deficiencies and their remediation on accrual quality. The Accounting Review 83 (1): 217-250.

6. Ashbaugh-Skaife, H., Collins, D., Kinney, W., LaFond, R. 2009. The effect of SOX internal control deficiencies on firm risk and cost of equity. Journal of Accounting Research 47 (1): 1-43.

7. Balsam, S., Jiang W. 2009. Equity incentives and internal control weaknesses. American Accounting Association Annual Meeting. Accessed July 14, 2009, http://aaahq.org/AM2009/abstract.cfm?submissionID=2347 July 14, 2009

8. Bartov, E., Mohanram, P. 2004. Private information, earnings manipulations, and executive stock-option exercises. The Accounting Review 79 (4): 889-920.

9. Beasley, M. 1996. An empirical analysis of the relation between the board of director composition and financial statement fraud. The Accounting Review 71 (4): 443-465.

10. Belkhir, M. and Chazi, A. 2010. Compensation vega, deregulation, and risk-taking: Lessons from the US banking industry. Journal of Business Finance \& Accounting. 37(9) \& (10): 1218-1247. 
11. Beneish, D., Billings, M., Hodder, L. 2008. Internal control weaknesses and information uncertainty. The Accounting Review 83 (3): 665-703.

12. Bergstresser, D., Philippon, T. 2006. CEO incentives and earnings management. Journal of Financial Economics 80: 511-529

13. Bronson, S., Carcello, J., Raghunandan, K. 2006. Firm characteristics and voluntary management reports on internal control. Auditing: A Journal of Practice \& Theory 25(2): 25-39.

14. Brown, K., and J. Lim. 2012. The effect of internal control deficiencies on the usefulness of earnings in executive compensation. Advances in Accounting 28 (1): 75-87

15. Burks, J. 2010. Disciplinary measures in response to restatements after Sarbanes-Oxley. Journal of Accounting and Public Policy 29 (3): 195-225.

16. Burks, J. 2011. Are investors confused by restatements after Sarbanes-Oxley. The Accounting Review 86 (2): 507-539.

17. Burns, N., Kedia, S. 2006. The impact of performance-based compensation on misreporting. Journal of Financial Economics 79: 35-67.

18. Burns, N., Kedia, S. 2008. Executive option exercises and financial misreporting. Journal of Banking \& Finance 32 (5): 845-857.

19. Carter, M., Lynch, L., Zechman, S. 2009. Changes in bonus contract in the post-Sarbanes-Oxley era. Review of Accounting Studies 14 (4): 480-506.

20. Cheng, Q. Farber, D. 2008. Earnings restatements, changes in CEO compensation, and firm performance. The Accounting Review 83 (5): 1217-1250.

21. Cheng, Q., Warfield, T. 2005. Equity incentives and earnings management. The Accounting Review 80 (2): 441-476.

22. Cohen, D., Dey, E., Lys, T. 2008. Real and accrual-based earnings management in the pre- and postSarbanes Oxley periods. The Accounting Review 83: 757-787.

23. Collins, D., Masli, A., Reitenga, A., Sanchez, J. 2009. Earnings restatements, the Sarbanes-Oxley Act and the disciplining of chief financial officers. Journal of Accounting Auditing and Finance 24 (1): 1-34.

24. Core, J., Guay, W. 2002. Estimating the value of employee stock option portfolios and their sensitivities to price and volatility. Journal of Accounting Research 40: 613-630.

25. Cornett, M., Marcus A., Tehranian, H. 2008. Corporate governance and pay-for-performance: The impact of earnings management. Journal of Financial Economics 87: 357-373.

26. Dechow, P., Sloan, R., Sweeney, A. 1996. Causes and consequences of earnings manipulation: an analysis of firms subject to enforcement actions by the SEC. Contemporary Accounting Research 13 (1): 1-36.

27. De Franco, G., Y. Guan, and H. Lu. 2005. The wealth change and redistribution effects of Sarbanes-Oxley internal control disclosures. Working paper, University of Toronto.

28. Desai, H., Hogan, C., Wilkins, M. 2006. The reputational penalty for aggressive accounting: earnings restatements and management turnover. The Accounting Review 81 (1): 83-112.

29. Doss, M. 2004. Section 404 reports on internal control: impact on ratings will depend on nature of material weakness reported (October). Moody's Special Comment. Moody's Investors Service, Inc.

30. Doyle, J., Ge, W., McVay, S. 2007a. Determinants of weakness in internal control over financial reporting and the implications for earning quality. Journal of Accounting and Economics 44: 193-223.

31. Doyle, J., Ge, W., McVay, S. 2007b. Accruals quality and internal control over financial reporting. The Accounting Review 82 (5): 1141-1170.

32. Efendi, J., Srivastava, A., Swanson, E. 2007. Why do corporate managers misstate financial statements: the role of option compensation and other factors. Journal of Financial Economics 85 (3): 667-708.

33. Efron, B., Tibshirani, R. 1993. An Introduction to the Bootstrap. Chapman \& Hall, New York.

34. Efron, B., Tibshirani, R. 1997. Improvements on cross-validation: the .632+ bootstrap method. Journal of the American Statistical Association 92 (438): 548-560.

35. Erickson, M., Hanlon, M., Maydew, E. 2006. Is there a link between executive equity incentives and accounting fraud? Journal of Accounting Research 44 (1): 113-143.

36. Ettredge, M., C. Li, and L. Sun. 2006. The impact of SOX Section 404 internal control quality assessment on audit delay in the SOX era. Auditing, A Journal of Practice and Theory 25 (3): 1-23.

37. French, K., Fama, E. 2009. Data Library. Accessed March 10, 2010, http://mba.tuck.dartmouth.edu/pages/faculty/ken.french/data_library.html 
38. Feng, M., Chan, L., McVay, S. 2009. Internal control and management guidance. Journal of Accounting and Economics 48 (2-3): 190-209.

39. Feng, M., Ge, W., Luo, S., Shevlin, T. 2011. Why do CFOs become involved in material accounting manipulation? Journal of Accounting and Economics 51 (1-2): 21-36 doi:10.1016/j.jacceco.2010.09.005.

40. Froot, K. 1989. Consistent covariance matrix estimation with cross-sectional dependence and heteroskedasticity in financial data. Journal of Financial and Quantitative Analysis 24 (3): 333-356.

41. Ge, W. McVay, S. 2005. The disclosure of material weaknesses in internal control after Sarbanes-Oxley Act. Accounting Horizons 19 (3): 137-158.

42. Geiger, M. , North, D. 2006 Does hiring a new CFO change things? An investigation of changes in discretionary accruals. Accounting Review 81 (4): 781-809.

43. Ghosh, A., Marra A., Moon, D. 2010. Corporate boards, audit committees, and earnings management: Pre- and post-SOX evidence. Journal of Business Finance \& Accounting 37 (9) \& (10): 1145-1176.

44. Goh, B. W. 2009. Audit committees, boards of directors, and remediation of material weaknesses in internal control. Contemporary Accounting Research 26 (2): 549-579.

45. Goldman, E., Slezak, S. 2006. An equilibrium model of incentive contracts in the presence of information manipulation. Journal of Financial Economics 80 (2): 603-626.

46. Goncalves, S., White, H. 2005. Bootstrap standard error estimates for linear regression. Journal of the American Statistical Association 100 (471): 970-979.

47. Gong, G. 1986. Cross-validation, the jackknife, and the bootstrap: excess error estimation in forward logistic regression. Journal of the American Statistical Association 81 (393): 108- 113.

48. Gujarati, D. 1995. Basic Econometrics. $3^{\text {rd }}$ edition. McGraw-Hill, New York.

49. Hammersley, J., Myers, L., Shakespeare, C. 2008. Market reactions to the disclosure of internal control weaknesses and to the characteristics of those weaknesses under section 302 of the Sarbanes Oxley Act of 2002. Review of Accounting Studies 13 (1): 141-165.

50. Harris, J., Bromiley, P. 2007. Incentives to cheat: the influence of executive compensation and firm performance on financial misrepresentation. Organization Science. 18 (3): 350-367.

51. Hennes, K., Leone, A., Miller, B. 2008. The importance of distinguishing errors from irregularities in restatement research: the case of restatements and CEO/CFO turnover. The Accounting Review 83 (6): 1487-1519.

52. Hogan, C., Wilkins, M. 2008. Evidence on the audit risk model: Do auditors increase audit fees in the presence of internal control deficiencies? Contemporary Accounting Research 25 (1): 219-242.

53. Hoitash, U., Hoitash, R., Bedard, J. 2009. Corporate governance and internal control over financial reporting: a comparison of regulatory regimes. The Accounting Review 84 (3), 839-867.

54. Hoitash, U., Hoitash, R., Johnstone, K. 2012. Internal control material weaknesses and CFO compensation. Contemporary Accounting Research 29 (3): 768-803.

55. Hosmer, D., Lemeshow, S. 1989. Applied Logistic Regression. John Wiley \& Sons: New York.

56. Hranaiova, J., Byers, S. 2007. Changes in market responses to financial statement restatement announcements in the Sarbanes-Oxley era. Working Paper. Accessed March 10, 2008, http://ssrn.com/abstract=1319354

57. Indjejikian, R., Matejka, M. 2009. CFO fiduciary responsibilities and annual bonus incentives. Journal of Accounting Research 47 (4): 1061-1093.

58. Jensen, M., Murphy, K. 1990. Performance pay and top-management incentives. Journal of Political Economy 98 (2): 225-264.

59. Jiang, J., Petroni, K., Wang, I. 2010. CFOs and CEOs: who have the most influence on earnings management? Journal of Financial Economics 96 (3): 513-526.

60. Johnson, S. Harley, E., Tian, Y. 2009. Managerial incentives and corporate fraud: the sources of incentives matter. Review of Finance 13: 113-145.

61. Johnstone, K. M., C. Li, and K. H. Rupley. 2011. Changes in corporate governance associated with the revelation of internal control material weaknesses and their subsequent remediation. Contemporary Accounting Research 28 (1): 331-383.

62. Klein, A. 2002. Economic determinants of audit committee independence. The Accounting Review 77 (2): 435-452.

63. Krishnan, J. 2005. Audit committee quality and internal control: an empirical analysis. The Accounting Review 80 (2): 649-675. 
64. Larcker, D., Richardson, S., Tuna, I. 2007. Corporate governance, accounting outcomes and performance. The Accounting Review 82 (4): 963-1008.

65. Li, C., Sun, L., Ettredge, M. 2010. Financial executive quality, financial executive turnover, and adverse SOX 404 opinions. Journal of Accounting and Economics 50 (1): 93-110.

66. Marquandt, D. 1980. You should standardize the predictor variables in your regression models. Discussion of: a critique of some ridge regression methods. Journal of the American Statistical Association 75 (369): 87-91.

67. McVay, S., Nagar, V., Wei Tang, V. 2006. Trading incentives to meet the analyst forecast. Review of Accounting Studies 11: 575-598.

68. Mian, S. 2001. On the choice and replacement of chief financial officers. Journal of Financial Economics 60: $143-175$.

69. Moody's. 2006. The second year of section 404 reporting on internal control. Special Comment. New York: Moody's Investors Service, Global Credit Research.

70. O’Connor, J., Priem, R., Coombs, J., Gilley, K. 2006. Do CEO stock options prevent or promote fraudulent financial reporting? Academy of Management Journal 49 (3): 483-500.

71. Ogneva, M., Subramanyan, K., Raghunandan, K. 2007. Internal control weakness and cost of equity: evidence from SOX Section 404 disclosures. The Accounting Review 82 (5): 1255-1297.

72. Palmrose, Z-V., Richardson V., Scholz, S. 2004. Determinants of market reactions to restatement announcements. Journal of Accounting and Economics 37 (1): 59-90.

73. Public Company Accounting Oversight Board (PCAOB) 2004. Auditing Standard No. 2 - An audit of internal control over financial reporting performed in conjunction with an audit of financial statements.

74. Raghunandan, K., and D. Rama. 2006. SOX Section 404 material weakness disclosures and audit fees. Auditing: A Journal of Practice \& Theory 25: 99-114.

75. Sarbanes-Oxley Act of 2002, Pub. L. No. 107-204, 116 Stat. 745.

76. Srinivasan, S. 2005. Consequences of financial reporting failure for outside directors: evidence from accounting restatements and audit committee members. Journal of Accounting Research 43 (2): 291-334.

77. Steyerberg, E., Harrell, F., Borsboom, G., Eijkemans, M., Vergouwe, Y., Habbema, J. 2001. Internal validation of predictive models: efficiency of some procedures for logistic analysis. Journal of Clinical Epidemiology 54: 771-781.

78. Veenman, D., Hodgson, A., wan Praag, B. Zhang, W. 2011. Decomposing executive stock option exercises: Relative information and incentives to manage earnings. Journal of Business Finance \& Accounting 38 (5) \& (6): 536-573.

79. Zhang, I. 2007. Economic consequences of the Sarbanes-Oxley Act of 2002. Journal Accounting and Economics 44: 74-115.

80. Zhang, Y., Zhou, J., Zhou, N. 2007. Audit committee quality, auditor independence, and internal control weaknesses. Journal of Accounting and Public Policy 26 (3): 300-327. 


\section{$\underline{\text { NOTES }}$}

